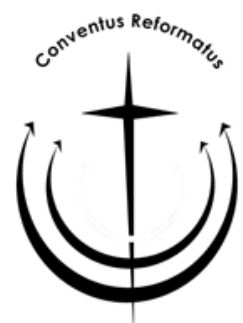

\title{
The influence of John Calvin's theology on the World Council of Churches
}

\author{
G.M.J. van Wyk \\ Nederduitsch Hervormde Kerk van Afrika \\ CAPE TOWN \\ E-mail: gafievw@mweb.co.za
}

\section{Abstract \\ The influence of John Calvin's theology on the World Council of Churches}

This article explores the question whether any traces of Calvin's theological views on church unity can be found in the purpose statements and goals of the World Council of Churches (WCC). Although no direct influence of Calvin's theology on the work of the WCC can be proved, the structure and content of Calvin's thought on church unity can be recognised in the statements and work of the WCC. Calvin believed that true church unity is not in the first place a unity of church structures, but one of truth, love, hope and confession. The ecumenical movement is in agreement with Calvin in this regard.

The ecumenical movement and the World Council of Churches are products of modern culture. The ecumenical movement could not have developed in a world that is not tolerant and where the free use of reason is not one of the core values of society. The ecumenical movement is also the natural answer to the problem of religious division that pre-modern Europe left us with. After a brief description of the World Council of Churches as a modern institution the influence of Calvin's theology on the theology of the World Council of Churches is explored.

\section{Opsomming}

\section{Die invloed van Johannes Calvyn se teologie op die Wêreldraad van Kerke}

Hierdie artikel ondersoek die vraag of enige spore van Calvyn se teologiese oortuigings in die funksiebeskrywings of doelwitte van die Wêreldraad van Kerke (WRK) gevind kan word. Alhoewel direkte beïnvloeding deur Calvyn se teologie nie in die werk van die WRK aangetoon kan word nie, kan die struktuur 
en sommige van sy denke oor kerkeenheid wel in sekere uitsprake en ander werk van die WRK herken word. Calvyn het geglo dat ware kerkeenheid nie in die eerste plek in kerklike strukture gesetel is nie, maar tot uitdrukking kom in waarheid, liefde, hoop en belydenis. In hierdie verband deel die ekumeniese beweging die oortuigings van Calvyn.

Die ekumeniese beweging en die Wêreldraad van Kerke is produkte van die moderne kultuur. Die ekumeniese beweging sou nie in 'n onverdraagsame wêreld kon ontwikkel waarin die vrye gebruik van die rede nie een van die sleutelwaardes van die gemeenskap is nie. Die ekumeniese beweging is die vanselfsprekende antwoord op die dilemma van godsdienstige verdeeldheid waarmee premoderne Europa ons gelaat het. Nadat 'n kort beskrywing van die Wêreldraad van Kerke as 'n moderne samelewingsinstelling gegee is, word die invloed van Calvyn se teologie op die teologie van die Wêreldraad van Kerke ondersoek.

\section{Introduction}

The World Council of Churches (WCC) identifies at least 23 church families or Christian traditions on it's website. Churches from most of these traditions are members of the WCC. One of these traditions is the reformed (or Calvinistic) tradition. Although many reformed churches as well as The World Communion of Reformed Churches (WCRC) are members of the WCC, it is obvious that the specific Calvinistic influence on the WCC would be limited. An organisation that accommodates such a variety of churches as members cannot give preference to one particular tradition. The method of inquiry in this article can therefore not be to identify specific Calvinistic theological statements in the documentation and publications of the WCC. Chances are good that such statements would be common to most Christian traditions rather than being specifically Calvinistic. I, therefore, choose for a more general approach. The question I want to explore is whether we find any traces of Calvin's theological views on church unity and ecumenism in the purpose statements and goals of the WCC.

\section{John Calvin's contribution to ecumenical theology}

In retrospect, Calvin can today be appreciated as an ecumenical theologian, although such a labelling is surely anachronistic. In a time of schism and even hostility in the church, Calvin stood out as a theologian that was consulted by many and who served those who consulted him with wise advice in the hope of contributing to church 
unity. He confronted many whom he believed were in error, but he was also seeking reconciliation all the time. In this article, however, it is not the example Calvin set for generations to come as an ecumenical participant that is important, but rather his theological contribution that can be used as a base for ecumenical theology.

Calvin's distinction between the visible church and the invisible church is often the point of departure in discussing Calvin's view on church unity (Hauschild, 1999:359). This is with good reason. Calvin himself discussed these two matters in relation to one another in his Institutes. We need, however, take into account that the doctrine of the visible and invisible church only became dominant at a later stage when it was the norm for ecclesiology for the orthodox development of the Reformation (Engelbrecht, 1978:291). Calvin did not take this distinction too far. He developed above all his notion of a church limited to one specific country or to a given territory in his expositions upon the church. Calvin certainly did not try to practice Platonic philosophy. He was only interested to think about the church from within his own concrete situation and tried to give answers to the questions of his own time. When Calvin speaks of the church, what he has in view most of the time are churches such as those of Geneva, Basle, and Strasbourg, or the different churches that finally grouped them into the church of France, Germany or the Netherlands (Wendel, 1978:310; Rohls, 1987:20-21). This does not mean that the church as a whole, lies outside his horizon. Calvin was, therefore, also very interested in the unity of the visible church of his own time. The unity he has in mind existed between all the churches that based themselves upon the pure gospel, whatever differences there might be among them concerning customs, ceremonies and organisation. The unity was, therefore, a unity based only on the truth of the one gospel of Christ. From the Institutes $(4.4 .7 ; 4.1 .8)$ it is clear that even within this context Calvin is thinking of the ecclesia universalis and the ecclesiae localis. For him the visible church needs to be one, because it includes all people from all over the world that are united in one faith and all institutions where the gospel is proclaimed in truth, where it is believed, and where the sacraments are administered and used according to its institution by Christ. We also need to keep in mind that the Reformation formulated its doctrine on the church in the context of the Roman Catholic Church's view that the unity of the church was to be in the institute itself - the office of the pope, the address or the succession of the clergy (Engelbrecht, 1978:292). Calvin wrote in the Institutes (4.1.7): 
Often, too, by the name of Church is designated the whole body of mankind scattered throughout the world, who profess to worship one God and Christ, who by baptism are initiated into the faith; by partaking of the Lord's Supper profess unity in true doctrine and charity, agree in holding the word of the Lord, and observe the ministry which Christ has appointed for the preaching of it.

In the Institutes 4.1 .9 he continues:

Wherever we see the word of God sincerely preached and heard, wherever we see the sacraments administered according to the institution of Christ, there we cannot have any doubt that the Church of God has some existence, since his promise cannot fail, 'where two or three are gathered together in my name, there am I in the midst of them'. (Matt. 18:20.)

Calvin did not understand truth or unity in a dogmatic sense (Matheson, 2000:125). Even divergences of doctrine that did not undermine the truth of the gospel should not break the unity of the church. He wrote, "... the fundamental doctrine, on which it is never allowable to compromise, is that we should learn Christ, for Christ is the one single foundation of the Church" (Commentary on 1 Cor. 3:11 quoted in Wendel, 1978:311). Therefore, Calvin can conclude:

The Church universal is the multitude collected out of all nations, who, though dispersed and far distant from each other, agree in one truth of divine doctrine, and are bound together by the tie of a common religion. (Letter to Cranmer, 1552 quoted in Wendel, 1978:310-311.)

The Archbishop of Canterbury once wrote to Calvin proposing a meeting of the principal leaders of Protestantism in Europe. Calvin replied:

... It must be counted among the worst evils of our epoch that the Churches are thus separated one from another, so much so that hardly any human society exists among us, still less that holy communion between the members of Christ which all profess but very few sincerely, cultivate in reality. (Letter to Cranmer, 1552 quoted in Wendel, 1978:310-311.)

One can also recall that just after his first ministry in Geneva he had done his best to keep his own partisans within the communion of his previous church in spite of the errors it had fallen into. Towards the end of his career he even put much effort in the establishment of an ecumenical university. 
The same concern for unity led Calvin to combat the schisms that were rending the church. He wrote in the Institutes (4.1.7-9):

We ought not to reject any assembly which entertains [the pure ministry of the Word and the pure manner of administering the sacraments] even though it be defective in several ways. What is more, there may be some defect either in the doctrine or in the manner of administering of the sacraments, which ought not in any way to alienate us from the communion of a Church. For not all the articles of the doctrine of God are of one and the same kind. The knowledge of some of them is so necessary that no one may doubt them, any more than the decrees or principles of Christianity: as, for example, that Jesus Christ is God and Son of God; that our redemption depends upon his mercy alone; and others like them. But there are others again that are in dispute between the Churches, without, however, disrupting their union.

The churches must never break their unity in dissensions over the inessential. Nor may the members of a church, on their own account, separate themselves individually:

Inasmuch as God wills that we should preserve the communion of his Church, by conversing in the company of the Church such as we see it among us, whoever separates himself from it is in great danger of withdrawing himself from the communion of the saints. (Commentary on 1 Cor. 3:11 quoted in Wendel, 1978:310-311.)

Calvin concludes his thought on church unity with regard to the reality of many different churches in the Institutes (4.1.9) with these words:

Thus we both maintain the Church universal in its unity, which malignant minds have always been eager to dissever, and deny not due authority to lawful assemblies distributed as circumstances require. True church unity is therefore not in the first place a unity of church structures, but one of truth, love, hope and confession.

\section{The modern world and the church}

When asking the question whether Calvin's theology has any influence on the thought of the WWC on church unity and ecumenism, we need to take into account that there are major cultural, historical and epistemological differences between the time of Calvin and our own time. Without going into any detail we need to give an account 
of the major patterns of thought and core values that distinguish our time from that of Calvin, and what the dominant reasons for these developments were.

Certainly the European Enlightenment is the most significant cultural and intellectual event since the time of the Reformation. The Enlightenment (Aufklärung) has determined, at least in part, what we think and do today. For most people enlightenment means that the human reason became the primary force to shape our lives. Enlightenment means that everything, including religion and faith, was subjected to the judgment of reason. The main advocate of the Enlightenment, Kant, and with him the philosopher Foucault, reminded us that there is actually more to Enlightenment than this. Although Kant (1983:53-61 [A481-A494]) advocated that people should have the courage to use the freedom they have to reason for themselves on what they need to do and what not, and not only live in a slavelike obedience to the authorities, he also pointed out that there are certain unavoidable restrictions to the free use of reason. Human reason is always determined by the particular circumstances and is therefore used with particular ends in view. One is also always reasoning as a member of a reasonable humanity. For this reason the free use of reason also poses a political problem. For this reason Kant proposes to Frederick II, the ruler of his own time, what might be called "the contract of rational despotism" (Foucault, 1984:37). Kant concluded that the public and free use of autonomous reason will be the best guarantee of obedience, on condition, however, that the political principle that must be obeyed itself, be in conformity with universal reason. What happened since the times of the early Reformation in Europe so that, during the lifetime of Kant, the free use of reason was valued as the most important core value for the whole society? What brought the whole intellectual community to the conviction that the freedom to reason guaranteed freedom as such or freedom for all? Up untill now, scholars very much agreed that the modern process of rationalisation was the main driving force in this development. Human reason established itself as the dominant cultural force of modern times through the rational development of a history of ideas. I am convinced that the process of modernisation was actually much more than the development of a history of ideas. The whole process was also rooted in cultural and political history. For this reason the European history of the later Reformation and the Contra-Reformation is of great importance to us (Bakhuizen van den Brink \& Dankbaar, 1967:234-280; Van Wyk, 2002:5-7). 
War broke out in the foremost European countries where the Reformation had influence during the time of the Contra-Reformation in the Roman Catholic Church. Although these wars had to do with the defence and promotion of national interests and ambitions, it was in the first place a power struggle between the Roman Catholics and the Protestants. A anachronistic continuation of these wars is the current strife in Northern Ireland. In France the Contra-Reformation was more anti-protestant than reformational. This was the primary reason why a civil war broke out between the Huguenots and the Roman Catholics. In total there raged eight religious wars in France between 1562 en 1593. In fact these eight wars were one long civil war interrupted by seven truces. These wars not only robbed France of the best of its citizens, but also brought it to total impoverishment.

War also broke out in Germany during 1618. This war continued for another 30 years. The war started as a civil war between different national parties in Germany, but developed into a European religious war. The war ended in a power struggle between Sweden and France on the one side and Habsburg on the other side for power over most parts of Europe. This war brought trouble and turmoil to the whole of central Europe.

The Dutch history is also important in this regard. Under the leadership of William of Orange the Dutch people rebelled against the central system of government of Philip II of Spain and the threats that the Spanish political policy caused their freedom and rights. When it seemed as if the Dutch aristocracy had only limited success against the Spaniards with their diplomacy, the Calvinists became impatient and took matters into their own hands. They were convinced that civil uprising against a tyrannical government was just. In the course of time the Dutch population was divided into two groups. On the one hand, there was the Catholics devoted to the thrown of Spain and on the other hand, the nationalistic minded Protestants.

The prime feature of all the religious wars of the sixteenth and seventeenth centuries was that no political or religious power could claim an absolute victory and that relative peace could only be negotiated by compromises. We must not underestimate the relationship between the reformation movement of the sixteenth century and the political consequences thereof in Europe. Retrospectively, it is clear that the religious wars that followed the Reformation brought about a new political dispensation in Europe. In this new political dispensation the relation between Christianity and the different European states, the church and civil society, and the different confessional groupings among each other were changed forever. The most sig- 
nificant structural changes brought about by these changes were that no confessional group in Europe could any longer make absolute claims about anything. In this manner the concept of tolerance became a leading concept not only in European politics, but also in the whole European culture and way of life. Because tolerance is such a fragile concept it can, however, only be maintained by putting in place all kinds of treaties between people and many legal measures (Van Wyk, 2002:7).

Because confessional unity could no longer be the basis for dealing with political, moral and legal questions, reflection on what is universally human became a necessity. The nature of man and natural law would become the basis for any fundamental reflection on any matter concerning man or society. When confessional unity was lost in Europe, religious convictions became private matters. It was not only the state that was emancipated from any religious bias. Economics, trade, science and the arts were also freed from any religious authority (Van Wyk, 2002:7). The time was now ripe for secular culture to develop. The table was set for the modern world to come about.

The ecumenical movement and the World Council of Churches are products of modern culture. The ecumenical movement could not have developed in a world that is not tolerant and where the free use of reason is not one of the core values of society. The ecumenical movement is also the natural answer to the problem of religious division that pre-modern Europe left us with. After a brief description of the World Council of Churches (as a modern institution) the question would be raised whether any traces of Calvin's theology can be found in the theology of the World Council of Churches.

\section{The World Council of Churches}

The World Council of Churches declares itself as a voluntary association of separated and autonomous Christian churches through which its members seek to manifest their fellowship with one another, to engage in common activities of witness and service, and to advance towards the goal of visible unity (Van Elderen \& Conway, 2001:5; Kessler \& Kinnamon, 2000:1). The quest for the unity of the church is at the heart of the ecumenical movement in general. The theological point of view of the council is that "shared life" is the norm and that division demands explanation. Our sinfulness, according to a statement on the council's website, is very much a fear of others; or since the pathology is deeper than that, a fear of otherness. By trusting God we can become new creatures, free to live no 
longer for ourselves, but for Jesus who died for us. As Christians we have a shared experience of grace. Now the church is called to be a sign of God's power to free and unite those who are oppressed and estranged.

The World Council of Churches (WCC) is the most inclusive among the many organised expressions of the modern ecumenical movement, a movement whose primary goal is the promotion of Christian unity (Kinnamon \& Cope, 1997:2, 79-80).

According to the information on the website of the WCC, the body brings together 349 churches, denominations and church fellowships in more than 110 countries and territories throughout the world, representing over 560 million Christians and including most of the world's orthodox churches, many anglican, baptist, Lutheran, methodist and reformed churches, as well as many united and independent churches. The member churches of the WCC come from Europe, North America, Africa, Asia, the Caribbean, Latin America, the Middle East and the Pacific. The WCC offers space to its members to reflect, speak, act, worship and work together, challenge and support each other, and debate with each other.

Church historians often refer to the nineteenth century as the century of mission and the twentieth century as the century of the ecumenical movement (Bakhuizen van den Brink \& Dankbaar, 1968:291). The modern ecumenical movement began in the late nineteenth and early twentieth century, when Christians began to come together across denominational boundaries. Early in the nineteenth century several movements had been formed to advance the cause of church unity. In 1937, church leaders agreed to establish a World Council of Churches (WCC). No progress was made with the actual organisation of the body because of the outbreak of the Second World War. During August 1948, when representatives of 147 churches assembled in Amsterdam, the WCC was formally constituted. Since then, a growing number of churches have joined the organisation. The world's largest Christian body, the Roman Catholic Church, is, however, not a member of the WCC. The Roman Catholic Church works closely with the Council and sends representatives to all major WCC conferences as well as to its central committee meetings and the assemblies. The Pontifical Council for Promoting Christian Unity has even appointed twelve representatives to the WCC's Faith and Order Commission.

The WCC denies that it ever wanted to build a global "superchurch". The council also does not want to standardise styles of wor- 
ship, but rather wants to deepen the fellowship of all the Christian churches and the different Christian communities so they may see in one another authentic expressions of the "one holy, catholic and apostolic church". Common confession of the apostolic faith, cooperating in mission and human service endeavours and sharing in the sacraments, are core values of the council (Kinnamon \& Cope, 1997:2). The council believes that all these acts of fellowship bear testimony to the foundational declaration of the WCC that the Lord Jesus Christ is "God and Saviour according to the Scriptures" (Van Elderen \& Conway, 2001:4). The essence of the council of churches is the relationship of the member churches to one another, and not their relationship to the structure of the council. The council of churches are no more than the fellowship of churches on the way to full koinonia. The sound theological basis for the council of churches depends on sincere fellowship between member churches, the acknowledgement that other member communions also belong to Christ, a deep ecumenical commitment from the participating churches and the readiness of the churches to be instruments of unity.

The basis of the council is not a full "confession of faith" such as the historic creeds and doctrinal decrees, but rather a brief expression of the faith and the commitment of the council formulated in the first article of it's constitution:

The World Council of Churches is a fellowship of churches which confess the Lord Jesus Christ as God and Saviour according to the scriptures, and therefore seek to fulfil together their common calling to the glory of the one God, Father, Son and Holy Spirit. (Van Elderen \& Conway, 2001:4.)

The primary purpose of the fellowship of churches in the World Council of Churches is to call one another to visible unity in one faith and in one eucharistic fellowship, expressed in worship and common life in Christ, through witness and service to the world, and to advance towards that unity in order that the world may believe. (Kessler, 1999:363.)

The WCC wants to be a truly ecumenical body. This means that its members' shared worship, dialogue, ecumenical advocacy, evangelism, social mission and witness and cooperation form the heart of the councils work. The council believes that when churches commit themselves to one another through service, witness, worship, study and dialogue, the isolating divisions of the past can be broken so that visible forms of unity can appear. 
According to Kessler and Kinnamon (2000:81-86), the most important challenges for the WCC are the following: maintaining of effective, flexible and robust ecumenical structures; relating the search for Christian unity to interfaith dialogue, without confusing the two; keeping the various ecumenical efforts together in one coherent movement; preserving appropriate theological diversity while standing firmly against so-called diversities that are contrary to the gospel; affirming appropriate cultural diversity while also claiming our unity in Christ; challenging the ecclesiological assumptions of the churches; turning the results of ecumenical dialogue into new ways of living together locally; expanding the circle of participants in the ecumenical movement; and recover and proclaim with passionate conviction the gospel-based vision of reconciliation in Christ that has historically been the heart of the movement.

\section{Conclusion}

The integration of the church into the political structures of Western society showed good prospects during the time of the Corpus Christianum. The identity and the unity of the church were more or less secured in the holy Roman Empire after 451 (Hauschild, 1995:147151). During the time of Calvin the church looked rather different. In 1054 a schism developed between churches in the West and the East. During the sixteenth century the church was further divided into different confessional groups and the political scene in Europe was reshaped by new national ambitions that grew in most countries. The relation between church and state became an ever-increasing problem for which new solutions had to be found. The situation developed over centuries to the point where secular or neutral states tolerate and accommodate most major religions. Churches on the other hand, are in most cases not pure national churches any more. They grew over national boundaries, through migration of people in the global village and their missionary expansion. Such global churches are a substantial group of the members of the WCC.

Calvin showed us the way to approach the complex question of church unity in the context of an ever-changing political reality. In his reflection on the issue he took into account the God-given reality that there is only one holy, catholic and apostolic church, that is also confessed by the church, the political reality that the church is divided for practical as well as confessional reasons, and the instruction that the church should be one. These principles are all cherished by the WCC and therefore the council is always seeking 
for new ways to serve the unity and reunification of the church. It is not easy to proof a direct influence of Calvin's theology on the work of the WCC. The structure and content of Calvin's thought on church unity can, however, be recognised in the statements and work of the WCC.

Calvin formulated his doctrine on church unity in the context of the Roman Catholic Church's view that the unity of the church was to be in the institute itself - the office of the pope, the address or the succession of the clergy. Calvin advocated that true church unity is not in the first place a unity of church structures, but one of truth, love, hope and confession. The unity he has in mind existed between all the churches that based themselves upon the pure gospel, whatever differences there might be among them concerning customs, ceremonies and organisation. It seems that the World Council of Churches share Calvin's point of view in this regard. The World Council of Churches denies that it ever wanted to build a global "super-church". The council also does not want to standardise styles of worship, but rather wants to deepen the fellowship of all the Christian churches and the different Christian communities so they may see in one another authentic expressions of the "one holy, catholic and apostolic church". Common confession of the apostolic faith, cooperating in mission and human service endeavours and sharing in the sacraments, are core values of the council.

When Calvin speaks of the church, he has in view most of the time churches such as those of Geneva, Basle, and Strasbourg, or the different churches that finally grouped them into the church of France, Germany or the Netherlands. The WCC shares this appreciation of the local church. The body tries to preserve appropriate theological diversity while standing firmly against so-called diversities that are contrary to the gospel, affirm appropriate cultural diversity while also claiming our unity in Christ and challenge the ecclesiological assumptions of the churches, turning the results of ecumenical dialogue into new ways of living together locally.

Calvin taught us that even if there may be some defect either in the doctrine or in the manner of administering of the sacraments, this may not alienate us from the communion of a church. Not all the articles of the doctrine of God are of one and the same kind. The knowledge of some of them is necessary and no one may doubt them, but there are others that are in dispute between the churches, without, however, disrupting their union. The WCC follows Calvin's view in this regard when it chooses a brief expression of the faith as it's basis and not a full "confession of faith" such as the historic 
creeds and doctrinal decrees. Calvin believed that the fundamental doctrine, on which it is never allowable to compromise, is that we should learn Christ, for Christ is the one single foundation of the church. The WCC comes close to this point of view when it confesses the Lord Jesus Christ as God and Saviour.

\section{List of references}

BAKHUIZEN VAN DEN BRINK, N.J. \& DANKBAAR, W.F. 1967. Handboek der kerkgeschiedenis. DI. 3: Reformatie en contra-reformatie. Den Haag: Bakker.

BAKHUIZEN VAN DEN BRINK, N.J. \& DANKBAAR, W.F. 1968. Handboek der kerkgeschiedenis. DI. 4: De kerk sedert de zeventiende eeuw. Den Haag: Bakker.

CALVIN, J. 1559. Institutes of the Christian religion. Trans. by $\mathrm{H}$. Beveridge. http://www.ccel.org/ccel/calvin/institutes.i.html Date of access: 14 Aug. 2009.

ENGELBRECHT, B.J. 1978. Die onderskeiding tussen "onsigbare" en "sigbare" kerk en die betekenis daarvan ten opsigte van die eenheid van die kerk, in teologie in die kerk. Pretoria: HAUM.

FOUCAULT, M. 1984. What is enlightenment? (In Rabinow, P., ed. The Foucault reader. London: Penguin Books. p. 32-50.)

HAUSCHILD, W-D. 1995. Lehrbuch der Kirchen- und Dogmengeshichte. Band 1: Alte Kirche und Mittelalter. Gütersloh: Gütersloher Verlagshaus.

HAUSCHILD, W-D. 1999. Lehrbuch der Kirchen- und Dogmengeshichte. Band 2: Reformation und Neuzeit. Gütersloh: Gütersloher Verlagshaus.

INSTITUTES see CALVIN. 1559

KANT, I. 1983. Beantwortung der Frage: Was ist Aufklärung? TI. 9. Herausgegeben von Wilhelm Weischedel. Darmstadt: Wissenschaftlichen Buchgesellschaft.

KESSLER, D. 1999. Together on the way. Official report of the Eighth Assembly of the World Council of Churches. Geneva: WCC.

KESSLER, D. \& KINNAMON, M. 2000. Councils of churches and the ecumenical vision. Geneva: WCC Publications.

KINNAMON, M. \& COPE, B.E. 1997. The ecumenical movement: an anthology of key texts and voices. Geneva: WCC.

MATHESON, P. 2000. The imaginative world of the Reformation: Edinburgh: Clark.

ROHLS, J. 1987. Theologie reformierter Bekenntnisschriften. Göttingen: Vandenhoeck \& Ruprecht.

VAN ELDEREN, M. \& CONWAY, M. 2001. Introducing the World Council of Churches. Geneva: WCC.

VAN WYK, G.M.J. 2002. Vind daar tans weer 'n paradigmaverandering in die teologie plaas? Pretoria: Universiteit van Pretoria. (Ongepubliseerde voordrag.)

WCC

see WORLD COUNCIL OF CHURCHES

WENDEL, F. 1978. Calvin. The origins and development of his religious thought. Trans. by P. Mairet. London: Collins. 
WORLD COUNCIL OF CHURCHES. 2009. http://www.oikoumene.org/ Date of access: 31 Aug. 2009.

\section{Key concepts:}

church unity

ecumenical

World Council of Churches

\section{Kernbegrippe:}

ekumenies

kerkeenheid

Wêreldraad van Kerke 